\title{
CONSERVED HAIRPIN IN THE NUCLEAR ITS1 OF PLEUROCARPOUS MOSSES AND ITS PHYLOGENETIC SIGNIFICANCE
}

\section{КОНСЕРВАТИВНАЯ ШПИЛЬКА ITS1 ЯДЕРНОЙ ДНК У БОКОПЛОДНЫХ МХОВ И ЕЕ ФИЛОГЕНЕТИЧЕСКОЕ ЗНАЧЕНИЕ}

\author{
IRINA A. MiLYUTINA ${ }^{1} \&$ MiCHAEL S. IGNATOV ${ }^{2}$ \\ ИРИНА А. МИЛЮТИНА ${ }^{1}$, МИХАИЛ С. ИГНАТОВ 2
}

Abstract

\begin{abstract}
The secondary structure of the nuclear ITS1 transcript in pleurocarpous mosses has one hairpin which is remarkably stable over families of Hypnales and Hookeriales, but is different in Ptychomniales and basal pleurocarps. The structure and transformation modes in this hairpin are described and its possible usage as a phylogenetic marker is discussed.
\end{abstract}

Резюме

Вторичная структура транскрипта ядерного внутреннего транскрибируемого спейсера 1 у бокоплодных мхов имеет шпильку, высоко консервативную у эволюционно продвинутых порядков Hypnales и Hookeriales, но уже сильно отличающуюся у сестринской к ним группы Ptychomniales и родственных групп. Обсуждается структура и преобразования этой шпильки в контексте филогении бокоплодных мхов.

KEYWORDS: RNA secondary structure, ribosomal internal transcribed spacer, Hypnales, Hookeriales, Ptychomniales, phylogeny

\section{INTRODUCTION}

The nuclear ribosomal internal transcribed spacers, ITS1 and ITS2, are markers widely used for phylogenetic reconstructions, and they attract considerable attention for various reasons. In many groups of plants, they are useful for phylogenetic studies at the species and genus level, being more variable than any chloroplast region in most groups. The secondary structure of ITS2 was found to be fairly conserved, having a core structure with four hairpins that are common for both plants and animals (Joseph et al., 1999; Schultz et al., 2005; Koetschan et al., 2009). Typically, ITS1 is more variable than ITS2, and its secondary structure has no definite core pattern like that of ITS2. This absence of an universal core structure is probably a case of greater variability of ITS1 sequence. Conserved sequence motifs in ITS1 in one group of organisms do not correspond to those from other groups (Gottschling \& Plötner, 2004; Wang et al., 2006).

In many acrocarpous moss families, ITS 1 is very variable mainly due to insertion and deletion events (indels). For example in Schistidium (Grimmiaceae), its 5'-end hairpin undergoes considerable changes, so sequences are difficult to align unequivocally (Milyutina et al., 2010) and almost impossible to align with the genus Grimmia, in which it is nested according to all chloroplast gene phylogenies (Hernández-Maqueda et al., 2008). Simi- larly the ITS tree of Philonotis had to be rooted on the earliest-diverging species of the same genus, as no other genus of the Bartramiaceae could be used for this purpose due to large ITS sequence divergence (Koponen et al., 2012). Similar examples can be found among analyses of the Pottiaceae (Fedosov \& Ignatova, 2008; Ignatova et al., 2013), Encalyptaceae (Fedosov, 2012).

By contrast, the ITS1 of pleurocarpous mosses is strikingly different, and it has been used successfully in phylogenetic analyses that included most families of Hypnales, Hookeriales and sometimes Ptychomniales ( $c f$. Gardiner et al., 2005; Ignatov et al., 2007; Huttunen et al., 2012).

The Hypnales form a monophyletic terminal clade in the phylogenetic tree of mosses in many analyses (e.g., Shaw et al., 2003; Tsubota et al., 2004; Cox et al., 2010; Huttunen et al., 2012).This is the latest diverged large clade of bryophytes. However, on the time scale Hypnales is not young whereas evolved in the early Cretaceous, ca. $138 \mathrm{Myr}$ ago, according to molecular phylochronology (Newton et al., 2007), a date which is principally congruent with fossil evidence (Ignatov \& Shcherbakov, 2007). In modern biota, Hypnales comprise about a half of all of moss species, ca. 4400 (Huttunen et al., 2012), while the total moss diversity in the world is in between 9000 and 13000 species (Magill, 2010). By the

1_ Lomonosov Moscow State University, Belozersky Institute of Physico-Chemical Biology, Moscow 119991 Russia - Poccия 119991 Москва, МГУ, НИИ Физико-химической биологии им. А.Н. Белозерского; e-mail: iramilyutina@yandex.ru

2 - Tsitsin Main Botanical Garden, Russian Academy of Sciences, Botanicheskaya 4, Moscow 127276 Russia - Россия 27276 Москва, Ботаническая, 4, Главный ботанический сад им. Н.В.Цицина РАН; e-mail: misha_ignatov@list.ru 

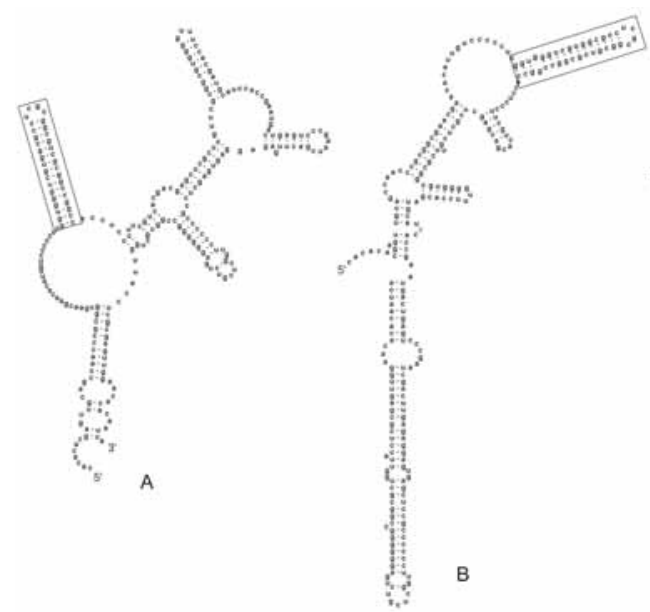

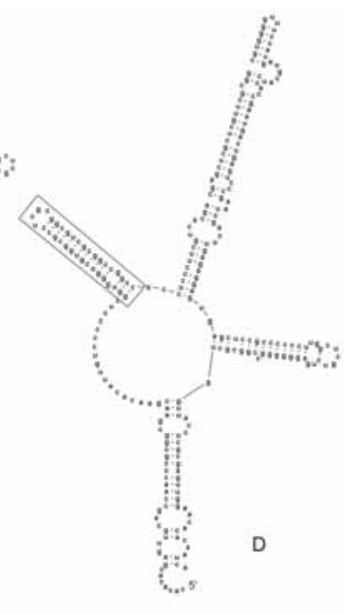

Fig. 1. Optimal (A) and three suboptimal structures (B, C, D), ranking according to ДG as \#3, \#4 and \#5; the \#2 is not shown) of Actinothuidium hookeri (AY568547) predicted by M-Fold. Illustrations show various structures, but $\mathrm{H} 1$ hairpin (boxed) is invariably present in all predictions. biomass Hypnales species exceed any other order excepting maybe only Sphagnales, as they dominate in ground layer in boreal forests and in tropical mossy forests pleurocarps also prevail.

Preliminary analysis of the secondary structure of the ITS1 transcript has revealed that almost all species of Hypnales have a hairpin near 5'-end, which has a conspicuously constant secondary structure. This hairpin denoted as $\mathrm{H} 1$ occurs in a fairly conservative GC-rich region and is typically $36-41 \mathrm{bp}$ long. The present study focuses on this conserved region to further define sequence variation in the hairpin and to determine if it could be an informative phylogenetic marker. Two related orders were taken for comparison, Hookeriales (sister to Hypnales) and Ptychomniales (sister to Hypnales+ Hookeriales). Members of distantly related families were not included as sequences of the hairpin near 5'-end of
ITS1 were too dissimilar in Aulacomniaceae, Aulacomnium (e.g., FJ823761), Hypnodendraceae, Hypnodendron (FM161142), Leptostomataceae, Leptostomum (KC995168), Mniaceae, Mnium (e.g., EU87819), and Spiridentaceae, Spiridens (HQ443771).

\section{MATERIAL AND METHODS}

The complete set of ITS1 sequences, 4787 accessions, was downloaded from NCBI GenBank on May 26, 2011 (search: 'Bryophyta and internal transcribed spacer 1'). Representatives of Hypnales, Hookeriales and Ptychomniales were retained, while representatives of other orders were deleted. From 2847 sequences of these 3 orders 298 were deleted by three reasons (1) sequences were missing the 5'-end of ITS1; (2) presence of ambiguous sites (N's); (3) the sequences were found to be likely misattributed to mosses, as BLAST showed them most similar to other groups of organisms. This trapping resulted

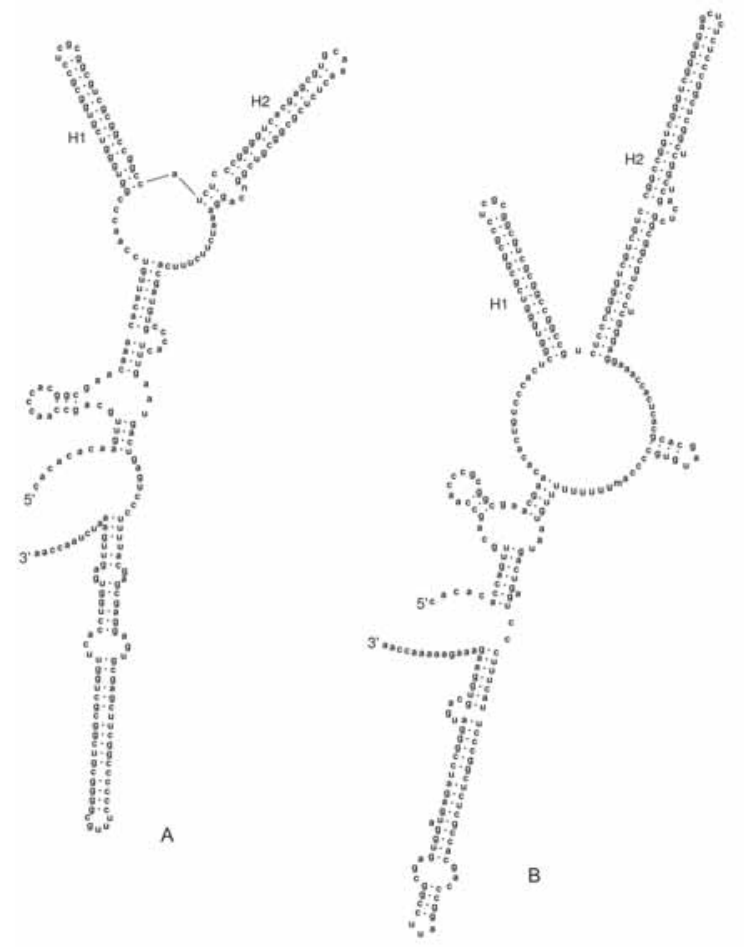

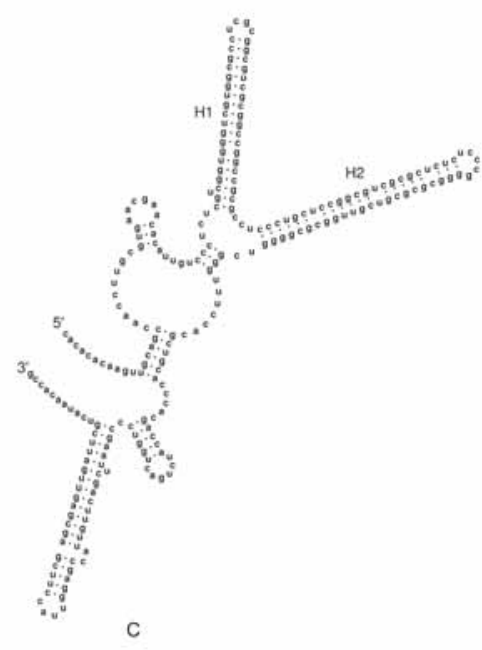

Fig. 2. Secondary structures predicted by M-Fold showing stable structure of $\mathrm{H} 1$ hairpin: A. Habrodon perpusillus (AY528880); B. Brachelyma subulatum (AF192094); C. Calliergonella cuspidata (AF168145). Note that H2 is much more variable than $\mathrm{H} 1$. 


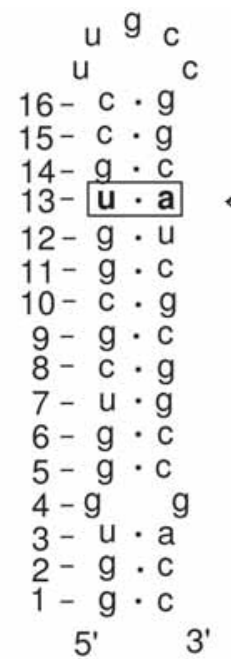

b

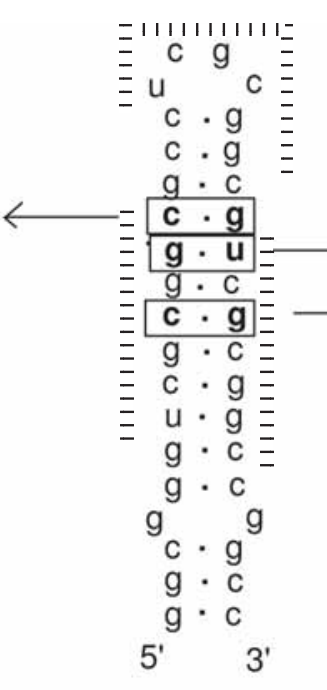

a

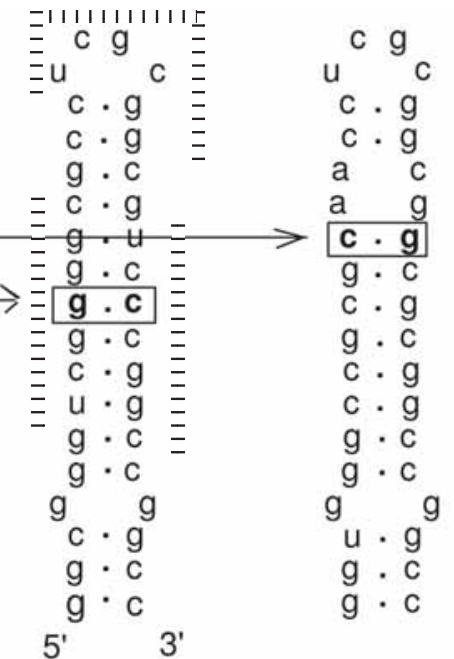

Fig. 3. Compensatory base changes in Hypnales and Hookeriales (arrowed and boxed): a. Hygroamblystegium fluviatile (AF464979), the basic type; b. Homalia pennatula (FM161125); c. Brachytheciastrum collinum (DQ200071); d. Dixonia thamnioides (FM161097). Three repeats UCGYGGC are marked in a and $\mathbf{c}$. in 2555 sequences of 647 species. However as phylogeographic studies often use ITS, and, obviously, some species are overrepresented in this set, many or even all samples of some species are identical. After removal of the identical sequences of one species, 818 sequences retained; they formed the basis for the set analyzed below. To complete it we added five new sequences of Ptychomniaceae and two of Sematophyllaceae (see Appendix 1; protocol and sequencing were standard, see e.g. Gardiner et al., 2005), and thus the final set comprised 825 ITS1 sequences of 647 species from ca. 45 families of Hypnales, 27 ITS1 sequences of 24 species from 6 families of Hookeriales, and 11 sequences of 10 species Ptychomniales. Authors of names in the whole text follow the TROPICOS database (www.tropicos.org).

A preliminary analysis of 70 species from 30 families of Hypnales by building their complete ITS1 secondary structures of the RNA transcripts of by Mfold (Zuker, 2003) revealed a very stable hairpin near its 5 '-end. In order to evaluate its stability, we examined optimal and five suboptimal structures for each sequence, and found again the invariable presence of $\mathrm{H} 1$ in all cases, despite overall topology predicted by MFold were quite different (Figs. 1, 2).

Further on, we studied H1 region sequences in Hypnales, Hookeriales and Ptychomniales, manually cutting from the alignment other parts of ITS1 in the BioEdit (Hall, 1999).

\section{RESULTS}

Basic structure of H1 hairpin secondary structure

\section{in Hypnales}

In the vast majority of Hypnales and Hookeriales, the number of hairpins in optimal and suboptimal structures was found to be different, varying from 4 to 7 per an individual sequence. However, all these structures, both optimal and suboptimal, shared one hairpin (H1), starting from ca. 50th base from 5 ' end, which remained unchanged (Figs. 1, 2).
The most common H1 structure in Hypnales and Hookeriales is shown in Fig. 3; it is formed by a stalk of 16 pairs of nucleotides and an apical loop of 4-6 nucleotides. Three repeats UCGYGGC occurs in most species (marked in Figs. 3a, 3c, 4c, 4d). A few groups (Brachytheciaceae: Donrichardsia, Oxyrrhynchium and Palamocladium; Trachylomataceae; Sematophyllaceae; Hypopterygiaceae: Canalohypopterygium) have some differences, which will be discussed below. Details of the $\mathrm{H} 1$ hairpin structure are given in Tables 1 and 2.

Single nucleotide polymorphism in $\mathrm{H} 1$ and its significance as specific marker

Point mutations in $\mathrm{H} 1$ are rare and in many cases do not correlate with any systematic units (note that the studied set includes species from ca. 50 families). There are only few examples where substitutions are phylogenetically informative. For example, $\mathrm{C}$ is substituted by $\mathrm{G}$ in 8th pair in 5'-chain of both studied species of $\mathrm{Lo}$ pidium, L. concinnum and L. struthiopteris, and no else species. In positions where substitutions are more common, e.g. in 10th pair in 5'-chain, most species have T, while all the Lopidium have $\mathrm{C}$; however in this case $\mathrm{C}$ is not unique for Lopidium but occurs also: (1) in all other Hypopterygiaceae, the family to which Lopidium belongs; (2) in all Fontinalaceae; (3) in many genera of Leskeaceae-Thuidiaceae-Amblystegiaceae-complex; (4) in the Brachytheciaceae subfamily Eurhynchioideae (Rhynchostegium, Eurhynchium s. str. and Plasteurhynchium). All species recently transferred from Rhynchostegium to genera of the subfamily Helicodontioideae, Donrichardsia and Hedenaesia (Huttunen \& Ignatov, 2010) lack $\mathrm{C}$ in this position, supporting that they do not belong to Eurhynchioideae. This and numerous similar examples demonstrate strong potential phylogenic value of common substitutions in $\mathrm{H} 1$, useful for, e.g., barcoding purposes. 


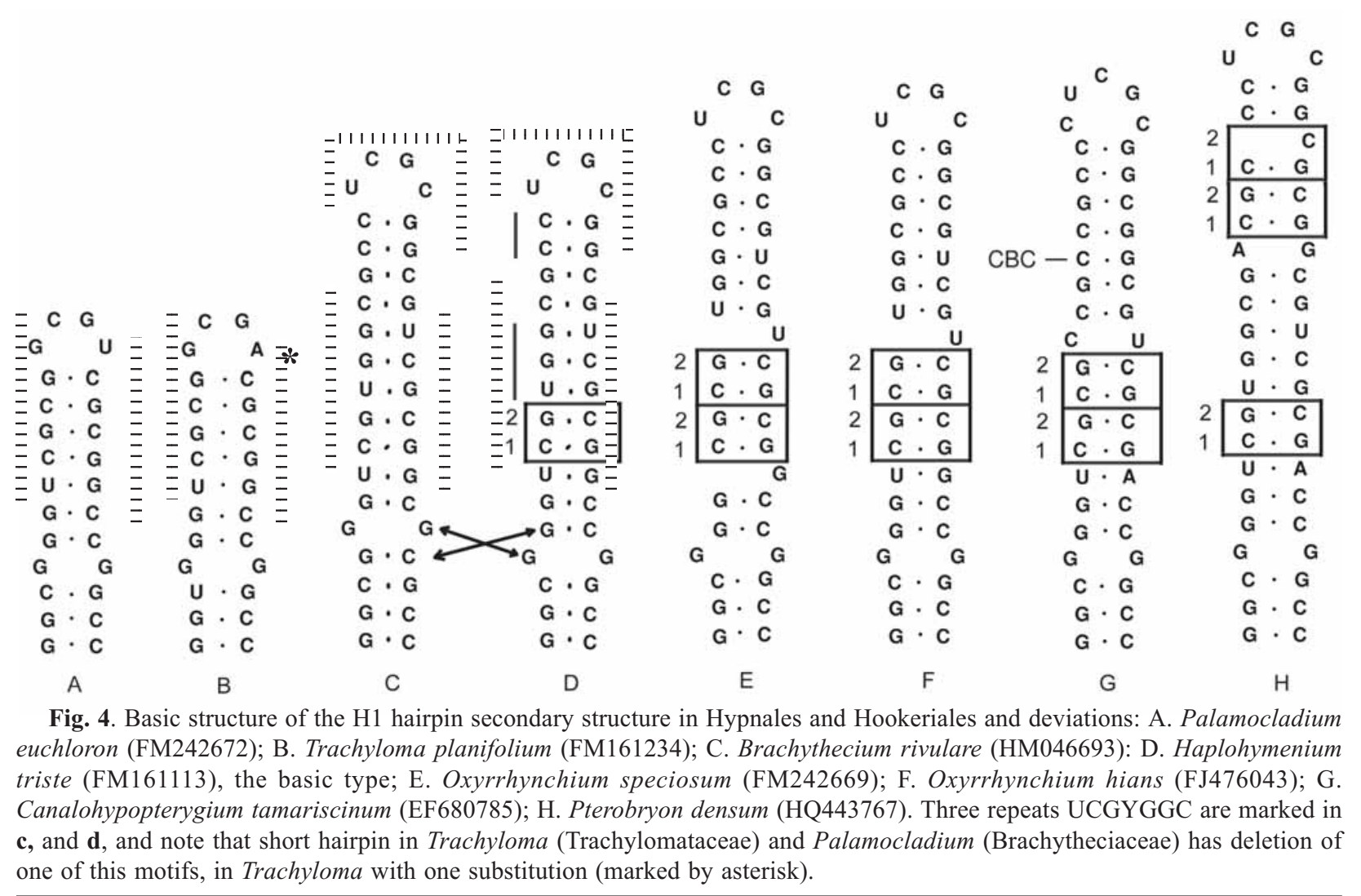

\section{Compensatory base changes (CBC)}

Leaving out SNP (single nucleotide polymorphism), the most widespread $\mathrm{H} 1$ composition can be deduced from its polymorphism shown in Table 1. It occurs in many genera, and selecting one of them, Hygroamblystegium fluviatile, AF464979 (Fig. 3 a), as an "average" for definiteness, we analyzed compensatory changes in the present set. Only seven out of 825 studied sequences were found to have compensatory changes, and Fig. 3 illustrates six of them; also one CBC in Sematophyllaceae is shown in Fig. 5.

Six CBC shown in Fig. 3 are as follow: Compared to the hairpin H1 Hygroamblystegium fluviatile: in 13th pair in H1 of Homalia pennatula, FM161125 (Fig. 3 b) CG is changed to UA; in 12 th pair in H1 of Dixonia thamnioides, FM161097, GU is changed to CG (Fig. 3 d); in 10th pair in H1 of 5 species from 4 not closely related genera, Brachytheciastrum collinum, DQ200071 \& EU567475, Dolichomitriopsis diversiformis, FM161098, Zelometeorium patulum, and Orthorrhynchium elegans (KC995166) YG is changed to GC (Fig. 3 c). In 7th pair of $\mathrm{H} 1$ of Acroporium lamprophyllum, JQ684532, UG is changed to GU (Fig. 5 C). In H1 of Canalohypopterygium tamariscinum (EF680785) GU is changed to CG in a way similar to that in Dixonia thamnioides, however due to duplication of two pairs, its position is in not in 12th, but in 15th position (Fig. $4 \mathrm{G}$ ).

Hemi-compensatory changes are numerous, they are mostly transitions from $\mathrm{C}$ to $\mathrm{U}$ in pairs with $\mathrm{G}$, and substitutions from UG to UA ( $c f$. Table 1).

\section{“Compensatory" insertions, deletions and trans- locations}

A. "Compensatory" insertions. Brachytheciaceae: Helicodontioideae, a group of species related to Oxyrrhynchium has $\mathrm{H} 1$ with 18 pairs in hairpin stalk, instead of 16. In Oxyrrhynchium and Donrichardsia (which sometimes is considered as a synonym of the former genus), there is an additional repeat of CG (Fig. $4 \mathrm{E}, \mathrm{F})$, and this repetition occurs in all numerous representatives of this group available in GenBank. Interestingly the same insertion occurs in a quite unrelated group of the Hypopterygiaceae, in Canalohypopterygium (Fig. $4 \mathrm{G}$ ). It is possible to assume that originally a $\mathrm{CG}$ repeat appeared in one chain due to replication slippage, and later reparation added two complementary bases in the other side of a hairpin. The longest H1 hairpin is found in Pterobryon densum (Fig.4H), but contrary to Oxyrrhynchium and Canalohypopterygium (Fig. 4E-G) it has two duplicated pairs in distal part of the hairpin.

B. "Compensatory" deletions. There are few examples where hairpin is shorter, 11 pairs instead of 16 , with the deletion of 5 pairs, and surprisingly, in unrelated groups, Trachyloma (Trachylomataceae) and Palamocladium (Brachytheciaceae) these deletions coincide (Fig. 4 A, B). Interestingly, they both shows a deletion of one of three seven-base motifs, UCGYGGC, so common for most Hypnales, although occasionally differing in one nucletodes (e.g. in Trachyloma, Fig. 4 B, asterisk). 

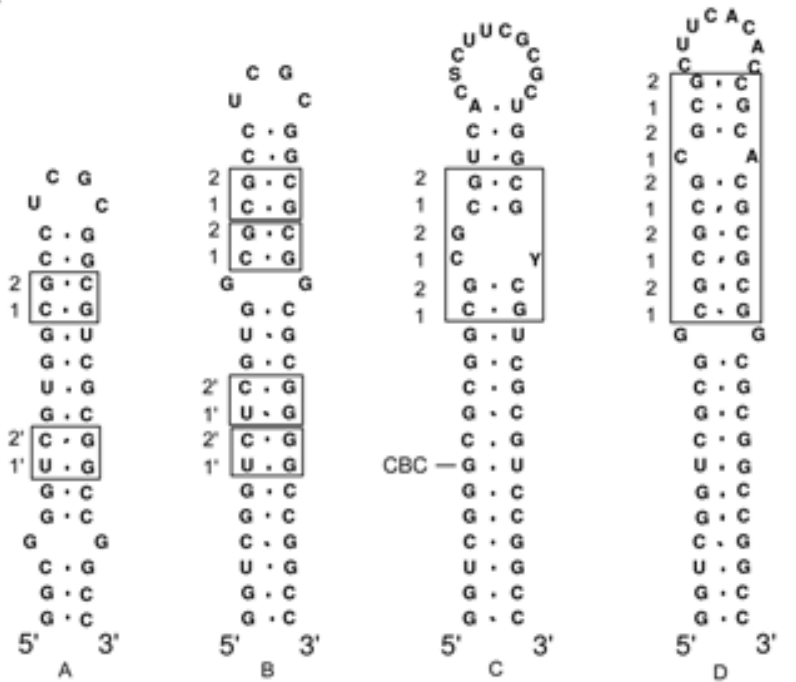

Fig. 5. Insertions in H1 hairpin of Sematophyllaceae: A. Haplohymenium triste (FM161113), the basic type; B. Trismegistia sp. (KC995167); C. Acroporium lamprophyllum (JQ684532); D. Sematophyllum homomallum (HE660022).

C. "Compensatory" translocations. In Myuroclada, Bryhnia and Brachythecium, in 4th pair in 3'-chain, G is substituted by $\mathrm{C}$ and due to this, the unpaired $\mathrm{GG}$, so characteristic for Hypnales, disappeared, but at the same time, in 5th pair, 3'-chain, $\mathrm{C}$ is substituted by $\mathrm{G}$, thus unpaired GG just shifts upwards along the hairpin to the next position (Fig.4, C, D). All Brachythecium species which were segregated into Sciuro-hypnum and Brachytheciastrum (Ignatov \& Huttunen, 2002) lack this pattern, so they are not different from most of Hypnales. Two unrelated species, Lopidium concinnum and Rhytidiadelphus loreus, have transversion $\mathrm{C}$ into $\mathrm{G}$ in 8 th position in 5 'chain, which results in unpaired GG, and in both cases this mutation correlates with the transversion $G$ into $U$ in the fourth position in 3' chain, which substitutes unpaired GG, a characteristic of most Hypnales, into G-U.

D. Hairpin H1 secondary structure in the Sematophyllaceae is exceptional (Figs. 5B-D). Its basal part, up to 6th pair, is similar to that in most Hypnales (with one exception of CBC in Acroporium), while the distal part is different. Trismegistia differs from Hypnales in two duplications (Fig. 5 B), of $7 \&$ 8th pairs and $13 \&$ 14th pairs. Distal part of H1 of Acroporium lamprophyllum and Sematophyllum homomallum possesses repeats of 13 $\&$ 14th pairs (CG), thus adding 2 pairs in Acroporium and 4 pairs in Sematophyllum. Unpaired GG in 4th pair, so characteristic of most Hypnales, does not occur in the studied Sematophyllaceae, however in Trismegistia and Sematophyllum this GG still exists in positions higher upon the hairpin stalk (Fig. 5B, D).

E. Hairpin H1 secondary structure in Ptychomniales (Fig. 6). Omitting from consideration a few exceptional cases, it is evident that the structure common to most Hypnales also occurs in Hookeriales. These two orders form a terminal clade, with its sister clade being the Ptychomniales, an or-
Table1. Positions in hairpin and contents of each position for the studied set of 825 specimens (H1 cf. Fig.1). 1 - substitutions at 5 'side, $\% ; 2-5$ 'side of hairpin stalk; $3-\mathrm{N}$ of pair; 4 - 3' side of hairpin stalk; 5 - substitutions at 3' side, $\%$.

\begin{tabular}{|c|c|c|c|c|}
\hline $\begin{array}{l}1 \\
\text { A-0 } \\
\text { G-0 } \\
\text { T- } 0,1\end{array}$ & C & 16 & $\mathbf{G}$ & $\begin{array}{l}5 \\
\mathrm{~A}-0 \\
\mathrm{C}-0 \\
\mathrm{~T}-0\end{array}$ \\
\hline $\begin{array}{l}\mathrm{A}-0 \\
\mathrm{G}-0 \\
\mathrm{~T}-0,1\end{array}$ & C & 15 & $\mathbf{G}$ & $\begin{array}{l}\mathrm{A}-0 \\
\mathrm{C}-0 \\
\mathrm{~T}-0,04\end{array}$ \\
\hline $\begin{array}{l}\text { A- } 0,3 \\
\text { C-0,08 } \\
\text { T-0 }\end{array}$ & G & 14 & C & $\begin{array}{l}\mathrm{A}-0,04 \\
\mathrm{G}-0 \\
\mathrm{~T}-0,08\end{array}$ \\
\hline $\begin{array}{l}\mathrm{A}-0,04 \\
\mathrm{G}-0,1 \\
\mathrm{~T}-0,67\end{array}$ & C & 13 & G & $\begin{array}{l}\mathrm{A}-0,23 \\
\mathrm{C}-0 \\
\mathrm{~T}-0\end{array}$ \\
\hline
\end{tabular}

A $-1,7$

C- $-0,12$

G

12

$\mathbf{T}$

A- $-0,04$

$\mathrm{T}-0,12$

A-0

$\mathrm{C}-0,04$

$\mathrm{T}-0$

G

A- 0,2

G- 0,31

C-13,7

A- 0,43

C $-0,08$

$\mathrm{T}-0,04$

G

9

11

C

G-2,49

C-1,18

A-0

G-0,63

$\mathrm{T}-5,9$

A- 0,87

C $-0,47$

T- $-0,59$

A- $-0,08$

A-0

G-0,32

T-0

A-0

C- $-0,08$

G- 0,04

A- 0,39

C-0

T-0

A-0

$\mathrm{C}-0$

T-0

A- 0,04

C $-0,35$

$\mathrm{T}-0,47$

G

4

C

G-0,08

$\mathrm{T}-1,1$

A- $-0,35$

C- 0,04

T-0

A-1,1

C -0

T- $-6,63$

A- 0,04

G- 0,04

$\mathrm{T}-0,12$

A-0

G-3,75

$\mathrm{T}-2,13$

A- 0,04

C $-3,87$

T-5,0

A-0

A- $-0,24$

C- 0,04

C- $-49,6$

G- 0,04

$\mathrm{T}-49,6$

Del-0,50

A-0

$\mathrm{C}-0$

T-0

A- 0

C- 0

T-0
G

2

C

A-0

G-0,04

$\mathrm{T}-0,75$

A-0,039

G

1

G-0
$\mathrm{T}-0,54$ 


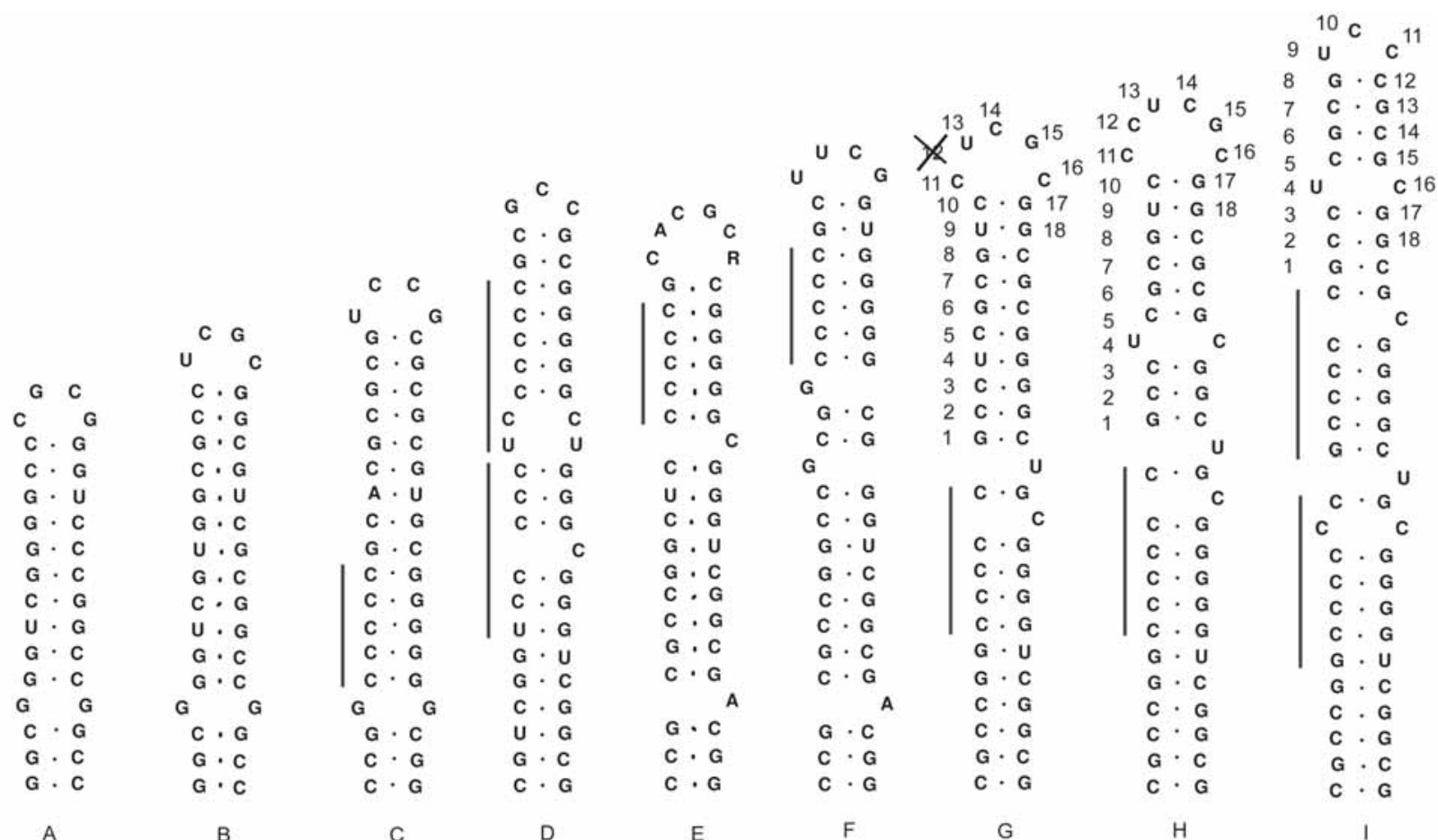

Fig. 6. Insertions in $\mathrm{H} 1$ hairpin of Ptychomniaceae: A. Orthorrhynchium elegans (KC995166); B. Haplohymenium triste (FM161113), the basic type in Hypnales, no insertions; C. Ptychomnion aciculare (JQ684530); D. Hampeella pallens (HE659999); E. Garovaglia powellii (HQ443748); F. Garovaglia binsteadtii (JQ684531); G. Cladomniopsis crenato-obtusa (HE659998); H. Glyptothecium sciuroides (KC995169); I. Euptychium robustum (KC995165). Polycytosine blocks are marked with vertical line in hairpin H1. Numbers in the three latter three species indicate replication slippage.

der that includes one family Ptychomniaceae with 13 genera and likely less than 50 species. The Ptychomniaceae were traditionally included in Hypnales until molecular phylogenetic results (based on nuclear 26S rDNA, two chloroplast and one mitochondrial loci) showed its distinct position (Buck et al., 2004; Goffinet et al.,2009).

The hairpin H1 secondary structure in the Ptychomniaceae remains stable among optimal and suboptimal structures for each species, but the intrageneric and sometimes intraspecific variation is much greater than in Hypnales. Hairpin stalk varies from 18 to 28 base pairs.

The hairpin H1 in the Ptychomniaceae is characterized by cytosine insertions (Fig. 6), which may be one or two in the 5'-chain and also in the terminal loop, and also dinucleotide (GC) repetitions, similar to that in the Sematophyllaceae. These insertions shift homologous sequence motifs in different genera to other portions within the secondary structures of H1. In one example of such slippage (Fig. 6) nucleotides of these motifs for Euptychium robustum (I), Glyptothecium sciuroides $(\mathrm{H})$ and Cladomniopsis crenatoobtusa $(\mathrm{G})$, are numbered showing how the terminal loop can become formed by part of stalk of 5'-side. Another example is provided by Ptychomnion aciculare (C) and Garovaglia binsteadii (F), where one motif, 5'-CCCCCGCACGCGCG-3', forms 5'-side of stalk in the former, while it is shifted in the latter so one of its parts forms a loop and one part the 3 '-side. No compensatory base changes were found in the studied set of Ptychomniales.
One species of Ptychomniales, Cladomnion ericoides has a very different beginning of ITS1. First 50 bases from the 5 '-end are duplicated, and the following two hairpins are formed by two direct repeats of 29 nucleotides. Similarly extensive duplications were noted earlier in ITS1 for an acrocarpous moss genus Schistidium, where they were, however, inverted (Milyutina et al., 2010).

\section{DisCUSSION}

Although the ITS1 is one of the most variable loci among the markers widely used in phylogenetic and phylogeographic studies of plants, some of its parts are quite conserved and are likely synapomorphic for the clade Hypnales plus Hookeriales, which diverged 138 Myr ago (Newton et al., 2007). This date indicates that the unique structure of $\mathrm{H} 1$ in Hypnales exists likely since the beginning of the Cretaceous, the time of about the origin of birds and flowering plants, showing a great stability of this part of ITS1 sequence within this phylum.

The H1 of Hypnales and Hookeriales has a unique structure: BLAST analyses do not find any similar sequences among other groups. This evidence supports the close affinity of Hypnales with Hookeriales to the exclusion of Ptychomniales, a result that is congruent with the phylogeny based on chloroplast and mithochondrial gene regions (Buck et al., 2004; Goffinet et al., 2009; Huttunen et al., 2012). Interestingly, Hampeella that appeared to be the most basal in Ptychomniales (Pedersen \& Newton, 2007; Huttunen et al., 2012) is the only genus of the order 
Table 2. Nucleotide contents of each position in the hairpin loop for the studied set of 825 specimens. In some cases the loop has additional positions at 5 '-end and the first nucleotide ( $\mathrm{T}$ in almost all cases) has been preceded in 15,1\% specimens by $\mathrm{C}$, in $0,23 \%$ by CC, in $0,35 \%$ by $\mathrm{T}$, in $0,04 \%$ by $\mathrm{TC}$, and in $0,04 \%$ by TCTC.

$\begin{array}{lll}\begin{array}{l}\text { Number } \\ \text { from }\end{array} & \begin{array}{l}\text { Nucleotides } \\ \text { of most } \\ 5^{\prime} \text { end }\end{array} & \text { Substitutions, in \% } \\ 1 & \text { T } & \\ 2 & \text { C } & \text { A }-0, \mathrm{G}-0,16, \mathrm{C}-0,16 \\ 3 & \mathrm{G} & \mathrm{A}-2,17, \mathrm{G}-0,04, \mathrm{~T}-0,24 \\ 4 & \mathrm{C} & \mathrm{A}-0,63, \mathrm{C}-0,24, \mathrm{~T}-0,55 \\ \end{array}$

that has unpaired GG in 4th pair, which is the most common case in the Hookeriales and Hypnales (Fig. 3).

Orthorrhynchium elegans was found to be the most basal taxon in the phylogeny of Ptychomniales, which is sister to Hypnales +Hookeriales crown clade of pleurocarpous mosses (Huttunen et al., 2012). However, Orthorrhynchium obviously has a Hypnales+Hookeriales-type of hairpin (Fig. 6 A), which never occurs in Ptychomniales. In the course of analysis of Huttunen et al. (2012), where the ITS was not used, chloroplast and mithochondrial data placed Orthorhhynchium near Ptychomniales. However, taking into account the signal from H1 hairpin structure, its closer relation to Hypnales+Hookeriales is more likely.

The presence of compensatory base changes (CBC) is considered indirect evidence of the stable presence of the hairpin secondary structure predicted by computer modelling (Gottschling et al., 2001; Coleman \& Vacquier, 2002; Wang et al., 2006; Mullineux \& Hausner, 2009). There are only 7 CBC in the studied set of pleurocarpous mosses (Fig. 3), but there are more examples of other compensatory events, like "compensatory" deletions, insertions and translocations. Some examples are present in the Brachytheciaceae, in Donrichardsia and Oxyrrhynchium, where the replication slippage could result in additional loops on 5'- and 3'-sides of stalk, reparation of which resulted in an insertion of additional CG. However, in these two closely related genera (sometimes considered as one), the apical loop remains in the same position, not shifted as in Ptychomniales.

The hairpin in Ptychomniales lacks compensatory changes, but shows examples of replication slippage. Its potential markers are mono- (CC) and dinucleotide (CGCG) repeats (Hancock \& Dover, 1990; Mullineux \& Hausner, 2009). Replication slippage may play an important role in the diversification of ITS1 sequences. Our results support the conclusion of Hancock \& Vogler (2000) that this slippage leads to "self-organization" when short repeats and point mutations recover consequences of indels in the opposite chain of hairpin stalk. Examples of "self-organization" of H1 in Ptychomniales lead to a conclusion that homologous motifs occur in different positions within the secondary structure of $\mathrm{H} 1$, thus the ho- mologization based upon positions in the secondary structure could be incorrect, due to replication slippages.

The secondary structure of 5'-end of ITS1 with two hairpins sitting upon a loop (Figs. 1-2) is not a rare case in other mosses, e.g., in Sphagnum and in Schistidium, varying sometimes greatly within a single genus, for example in Schistidium (Milyutina et al., 2010). A similar secondary structure occurs also in flowering plants and Dinoflagellatae (Gottschling \& Plötner, 2004; Liu \& Schardl, 1994), although not in all species. Thus, we confirm the tentative conclusion of Mai \& Coleman (1997) and Coleman et al. (1998) that the secondary structures of ITS1 are more conserved than the sequences themselves.

\section{ACKNOWLEDGEMENTS}

We are grateful to Alexey Troitsky for valuable comments on the manuscript, Anna Ivanova for English correction, and RFBR 12-04-00534 and 13-04-01592 for partial support of the study.

\section{LITERATURE CITED}

COLEMAN, A.W., R.M. PREPARATA, B. MEHROTRA \& J.C. MAI 1998. Derivation of the secondary structure of the ITS-1 transcript in volvocales and its taxonomic correlations. Protist 149: 135-146.

COLEMAN, A.W. \& V.D. VACQUIER. 2002. Exploring the phylogenetic utility of ITS sequences for animals:a test case for abalone (Haliotis). - J. Mol. Evol. 54: 246-257.

COX C.J., B. GOFFINET, N.J. WICKETT, S.B. BOLES \& A.J. SHAW 2010. Moss diversity: a molecular phylogenetic analysis of genera. Phytotaxa 9: 175-195.

FEDOSOV, V.E. 2012. Encalypta sect. Rhabdotheca in Russia. - Arctoa 21: $101-112$.

GARDINER, A., M. IGNATOV, S. HUTTUNEN \& A. TROITSKY. 2005. On resurrection of the families Pseudoleskeaceae Schimp. and Pylaisiaceae Schimp. (Musci, Hypnales). - Taxon 54: 651-663.

GOFFINET, B., W.R. BUCK \& A.J. SHAW. 2009. Morphology, anatomy, and classification of the Bryophyta. - In: Goffinet, B. \& A. J. Shaw (eds.) Bryophyte Biology, $2 d$ ed. Cambridge University Press: Cambridge: $55-138$.

GOTTSCHLING, M., H.H. HILGER, M. WOLF \& N. DIANE. 2001. Secondary structure of the ITS1 transcript and its application in a reconstruction of the phylogeny of Boraginales. - Plant. Biol. 3: 629-636.

GOTTSCHLING, M. \& J. PLÖTNER. 2004. Secondary structure models of the nuclear internal transcribed spacer regions and 5.8S rRNA in Calciodinelloideae (Peridiniaceae) and other dinoflagellates. - Nucl. Acids Res. 32: 307-315.

HALL, T.A. 1999. BioEdit: a user-friendly biological sequence alignment editor and analysis program for Windows 95/98/NT. - Nucl. Acids Symp. Ser. 41: 95-98.

HANCOCK, J.M. \& G.A. DOVER. 1990. Compensatory slippage" in the evolution of ribosomal RNA genes. - Nucl. Acids Res. 18: 5949 5954.

HANCOCK, J.M. \& A.P. VOGLER. 2000. How slippage-derived sequences are incorporated into rRNA variable-region secondary structure: implications for phylogeny reconstruction.-Mol. Phylogenet. Evol. 14: 366-374

HERNÁNDEZ-MAQUEDA, R., D. QUANDT \& J. MUÑOZ. 2008. Testing reticulation and adaptive convergence in the Grimmiaceae (Bryophyta). - Taxon 57: 500-510.

HUTTUNEN, S. \& M.S. IGNATOV. 2010. Evolution and taxonomy of aquatic species in the genus Rhynchostegium (Brachytheciaceae, Bryophyta). - Taxon 59: 791-808. 
HUTTUNEN, S., N. BELL, V.K. BOBROVA, V. BUCHBENDER, W.R. BUCK, C. J. COX, B. GOFFINET, L. HEDENÄS, B.-CH. HO, M.S. IGNATOV, O. KUZNETSOVA, I.A. MILYUTINA, A. NEWTON, S. OLSSON, L. POKORNY, J.A. SHAW, M. STECH, A. TROITSKY, A. VANDERPOORTEN \& D. QUANDT. 2012. Disentangling knots of rapid evolution: origin and diversification of the moss order Hypnales. - J. Bryol. 34: 187-211.

IGNATOV, M.S. \& S. HUTTUNEN. 2002. Brachytheciaceae (Bryophyta): a family of sibling genera. -Arctoa 11: 245-296.

IGNATOV, M.S., A.A. GARDINER, V.K. BOBROVA, I.A. MILYUTINA, S. HUTTUNEN \& A.V. TROITSKY. 2007. On the relationships of mosses of the order Hypnales, with special reference to taxa traditionally classified in the Leskeaceae. - In: Newton, A.E. \& R.S. Tangney (eds.), Pleurocarpous mosses: systematics and evolution. Syst. Assoc. Spec.Vol. 71: 177-213.

IGNATOV, M.S. \& D.E. SHCHERBAKOV. 2007. Did pleurocarpous mosses originate before the Cretaceous? - In: Newton, A.E. \& R.S. Tangney (eds.), Pleurocarpous mosses: systematics and evolution. Syst. Assoc. Spec.Vol. 71: 321-336.

FEDOSOV, V.E. \& E.A. IGNATOVA. 2008. The genus Bryoerythrophyllum (Pottiaceae, Bryophyta) in Russia. - Arctoa 17: 19-38.

IGNATOVA, E.A., O.I. KUZNETSOVA, M.S. IGNATOV \& H. KÖCKINGER. 2012. The genera Oxystegus and Pseudosymblepharis (Pottiaceae, Bryophyta) in the Caucasus. - Arctoa 21: 173-180.

JOSEPH, N., E. KRAUSKOPF, M.I. VERA \& B. MICHOT. 1999. Ribosomal internal transcribed spacer 2 (ITS2) exhibits a common core of secondary structure in vertebrates and yeast. - Nucl. Acids Res. 27(N23): 4533-4540.

KOETSCHAN, C., F. FÖRSTER, A. KELLER, T. SCHLEICHER, B. RUDERISCH, R. SCHWARZ, T. MÜLLER, M. WOLF \& J. SCHULTZ. 2010. The ITS2 Database III - sequences and structures for phylogeny. - Nucl. Acids Res. 38: D275-D279.

KOPONEN, T., E.A. IGNATOVA, O.I. KUZNETSOVA \& M.S. IGNATOV. 2012. The genus Philonotis (Bartramiaceae, Musci) in Russia.Arctoa 21: 21-62.

LEVINSON, G. \& G.A. GUTMAN. 1987. Slipped-strand mispairing: a major mechanism for DNA sequence evolution. - Mol. Biol. Evol. 4(3):203-221.

LIU, JIN-SHIOU \& C.L. SCHARDL. 1994. A conserved sequence in internal transcribed spacer 1 of plant nuclear rRNA genes. - Plant Molecular Biology 26:775-778.

MAGILL, R.E. 2010. Moss diversity: new look at old numbers. - Phytotaxa 9: 167-174.

MAI, J.C. \& A.W. COLEMAN. 1997. The internal transcribed spacer 2 exhibits a common secondary structure in green algae and flowering plants. - J. Mol. Evol. 44:258-271.

[MILYUTINA, I.A., D.V. GORYUNOV, M.S. IGNATOV, E.A. IGNATOVA \& A.V. ТROІТSКY] МИЛЮТИНА, И.А., Д.В. ГОРЮНОВ, М.С. ИГНАТОВ, Е.А. ИГНАТОВА, А.В. ТРОИЦКИЙ. 2010. Фило- гения мхов рода Schistidium (Bryophyta, Grimmiaceae) по нуклеотидным последовательностям и вторичной структуре внутренних транскрибируемых спейсеров ядерной рДНК. Молекулярная биология 44(6): 994-1009.

MULLINEUX, T. \& G. HAUSNER. 2009. Evolution of rDNA ITS1 and ITS2 sequences and RNA secondary structures within members of the fungal genera Grosmannia and Leptographium. - Fungal Genet. and Biol. 46(11): 855-867.

NEWTON, A. E., N. WIKSTRÖM, N. BELL, L.L. FORREST \& M.S IGNATOV. 2007. Dating the diversification of the pleurocarpous mosses. - In: Newton, A.E. \& R.S. Tangney (eds.). Pleurocarpous mosses: systematics and evolution. Syst. Assoc. Spec.Vol. 71: 337-366.

PEDERSEN, N. \& A.E. NEWTON. 2007. Phylogenetic and morphological studies within the Ptychomniales, with emphasis on the evolution of dwarf males. - In: Newton, A.E. \& R.S. Tangney (eds.), Pleurocarpous mosses: systematics and evolution. Syst. Assoc. Spec.Vol. 71: 367-392.

SCHULTZ, J., S. MAISEL, D. GERLACH, T. MÜLLER \& M. WOLF. 2005. A common core of secondary structure of the internal transcribed spacer2 (ITS2) throughout the Eukaryota. - RNA 11: 361-364.

SHAW, J., C.J. COX \& S.B. BOLES. 2003. Polarity of peatmoss (Sphagnum ) evolution: Who says mosses have no roots? $-A m$. J. Bot $\mathbf{9 0}$ : $1777-1787$

TSUBOTA, H., E. DE LUNA, D. GONZÁLEZ, M.S. IGNATOV \& H. DEGUCHI. 2004. Molecular phylogenetics and ordinal relationships based on analyses of a large-scale data set of $600 \mathrm{rbcL}$ sequences of mosses. - Hikobia 14: 149-170.

WANG, S., Z. BAO, N. LI, L. ZHANG \& J. HU. 2006. Analysis of the secondary structure of ITS1 in Pectinidae: implications for phylogenetic reconstruction and structural evolution. - Marine Biotechnol. 9: 231242.

ZUKER, M. 2003. Mfold web server for nucleic acid folding and hybridization prediction. - Nucleic Acids Res. 31(13): 3406-3415.

\section{APPENDIX}

GenBank accessions and specimens vauchers for specimens additionally sequenced for their ITS1. Cladomnion ericoides (Hook.) Wilson (New Zealand, Tan \& Fife 94-332, MHA) KC995164; Euptychium robustum Hampe (Australia, Streimann 56120, MHA), KC995165; Glyptothecium sciuroides (Hook.) Broth. (Australia, Streimann 55627, MHA), KC995169; Ptychomnion aciculare (Australia, Streimann 63818) JQ684530; Garovaglia binsteadii (Papua New Guinea, Koponen 29808, MHA) JQ684531; Leptostomum erectum R. Br. (Australia, Norris 61355, MHA), KC995168; Orthorrhynchium elegans (Hook. f. \& Wilson) Reichardt (Papua New Guinea, Norris 63985, MHA), KC995166; Trismegistia sp., (Malaysia, Ignatov 07-6000, MHA), KC995167, Acroporium lamprophyllum (Malaysia, Ignatov 07-5043, MHA) JQ684532 